\title{
Wznowienie postępowania w czeskim postępowaniu sądowoadministracyjnym
}

\author{
Reopening of proceedings in the Czech administrative court procedure \\ Возобновление производства в чешском судебно-административном \\ производстве
}

\author{
AGNIESZKA ZIÓŁKOWSKA \\ Dr hab., prof. Uniwersytetu Śląskiego \\ e-mail: agnieszka.ziolkowska@us.edu.pl, https://orcid.org/0000-0002-9933-2667
}

\begin{abstract}
Streszczenie: Aktem normatywnym regulujący postępowanie sądowoadministracyjne w Czechach jest Zákon soudní ŕád správní, który w części trzeciej wskazuje na dwa nadzwyczajne środki prawne przysługujące od prawomocnego wyroku: skargę kasacyjną oraz skargę o wznowienie postępowania sądowoadministracyjnego. Co istotne, w czeskim postępowaniu sądowoadministracyjnym znajdują zastosowania klasyczne podstawy wznowienia postępowania, takie jak nowe okoliczności i nowe dowody, których strona nie mogłaby wykorzystać bez swojej winy w pierwotnym postępowaniu. Katalog pozytywnych przesłanek skargi o wznowienie postępowania został określony w $\S 111$ s.r.s.s. Ponadto ustawodawca dokonał pozytywnej enumeracji postępowań, w których skarga o wznowienie jest dopuszczalna (§ 114 s.r.s.s.). Skarga o wznowienie postępowania nie ma charakteru dewolutywnego, a jej wniesienie wywołuje skutek względnie suspensywny. Postępowanie ze skargi o wznowienie postępowania sądowoadministracyjnego jest dwufazowe: w pierwszej kolejności (iudicium rescindens) następuje badanie zachowania warunków rozpoznania skargi o wznowienie. Ten etap kończy się wyrokiem o dopuszczalności wznowienia lub odrzuceniem skargi. Następnie przeprowadza się drugi etap (iudicium rescissorium) - postępowanie wznowieniowe, $w$ którym zachodzi merytoryczne rozpoznanie skargi.
\end{abstract}

Słowa kluczowe: skarga o wznowienie postępowania sądowoadministracyjnego, etapy postępowania wznowienowego, postępowanie sądowoadministracyjne

Summary: The normative act that regulates administrative court procedure in the Czech Republic is Zákon soudni r rád správní, which in part third provides for two extraordinary legal measures against a final judgment: the cassation appeal and the demand to reopen administrative court proceedings. Importantly, in the Czech administrative court procedure, the classical grounds for the reopening of proceedings are new circumstances and new evidence that a party to the proceedings could have used without their fault in the original proceedings. The catalogue of the positive conditions for the demand to reopen proceedings is provided for in $\S 111$ s.r.s. The legislator has positively enumerated court proceedings in which a demand to reopen proceedings is admissible ( $\$ 114$ s.r.s.). The demand to reopen proceedings does not have a devolutive character, and its submission has a relatively suspensive effect. Proceedings launched by the demand to reopen administrative proceedings encompass two phases: the first one (iudicium rescindens) involves the examination of the fulfilment of the conditions for the examination of the demand to reopen proceedings. This stage is concluded by a judgment so as to the admissibility of reopening, or rejecting the demand to reopen proceedings. The second stage (iudicium rescissorium), reopening the proceedings, consists in a substantive examination of the demand.

Key words: demand to reopen proceedings, stages of reopened proceedings, administrative court procedure

Резюме: Нормативным актом, регулирующим судебно-административное производство в Чешской Республике, является Zákon soudní ŕád správní, в третьей части которого указаны два чрезвычайных средства правовой защиты, доступных в отношении окончательного судебного решения: кассационная жалоба и жалоба о возобновлении судебно-административного производства. Важно отметить, что классические 
основания для возобновления производства, такие как новые обстоятельства и новые доказательства, которые не могли быть использованы стороной без ее вины в первоначальном разбирательстве, применимы в чешском административном судопроизводстве. Перечень положительных оснований для возобновления производства изложен в статье § 111 s.ř.s. Корме того, законодатель сделал положительное перечисление производств, в которых допустимо возобновление производства (§ 114 s.ř.s.). Жалоба о пересмотре не носит деволютивного характера, и его подача влечет за собой ограниченно суспензивный эффект. Производство по жалобе о возобновлении судебно-административного производства состоит из двух этапов: первый этап (iudicium rescindens) - это рассмотрение вопроса о том, соблюдены ли условия для рассмотрения жадобы о пересмотре. Эта стадия заканчивается вынесением решения о приемлемости возрождения или об отклонении жалобы. Затем следует вторая стадия (iudicium rescissorium) - процедура возобновления, в ходе которой рассматривается существо иска.

Ключевые слова: жалоба о возобновлении судебно-административного производства, стадии возобновления производства, судебно-административное производство

\section{Wstęp}

Konstytucja Republiki Czeskiej z 1992 r. $^{1}$ w przepisie zawartym w art. 91 stworzyła nowe podwaliny sądownictwa administracyjnego ${ }^{2}$. Zgodnie $\mathrm{z}$ treścią normy ujętej w ust. 1 wskazanego przepisu system sądownictwa tworzą: Sąd Najwyższy, Najwyższy Sąd Administracyjny, sądy apelacyjne ${ }^{3}$, okręgowe i rejonowe. Jednak do końca 2002 r. sądownictwo w sprawach administracyjnych nie było regulowane odrębnym aktem normatywnym i podlegało części piątej Kodeksu postępowania cywilnego. Fundamentalne znaczenie dla zmian w zakresie sądownictwa w sprawach administracyjnych stanowił wyrok (Nález) Sądu Konstytucyjnego z dnia 27 czerwca 2001 r. , który uchylił wspomnianą piątą część Kodeksu postępowania cywil-

1 Ústava České Republiky z dnia 16 grudnia 1992 r. Tego samego dnia przyjęto Kartę Podstawowy Praw i Wolności (Listina základních práv a svobod - Ústavní zákon č. 2/1993 Sb. z późn. zm.), a w niej $\mathrm{w}$ art. 36 ust. 2 stanowiący podstawy do odrodzenia sądownictwa administracyjnego. Karta następnie została włączona do konstytucji, zob. np. V. Sládeček, V. Tomaszková, Správní soudnictví v České republice a ve vybraných státech Evropy, Praha 2010, s. 42, V. Tomaszková, M. Tomoszek, Vliv Rady Evropy na správni soudnictvi a přistup ke správnim soudi̊m v Českè republice, w: Vliv EU a Rady Evropy na správni řizeni v ČR a v Polsku, red. M. Horáková, M. Tomaszek, Brno 2010, s. 242-243.

2 Szerzej o kształtowaniu się sądownictwa administracyjnego w Czechach zob. np. A. Ziółkowska, Postępowanie międzyinstancyjne w postępowaniu sądowoadministracyjnym, Katowice 2019, s. 364-366.

3 Przy czym, jak wskazuje M. Kruk-Jarosz (tłumaczenie Konstytucji Republiki Czeskiej, http://biblioteka.sejm.gov.pl), w Republice Czeskiej są dwa takie sądy. Do ich kompetencji należy także czuwanie nad wykładnią ustaw oraz ich przestrzeganie w postępowaniu sądowym i o zgodności z prawem działania innych organów. Organizację i zakres właściwości sądów określa ustawa (art. 91 ust. 2). Zob. też np. V. Mikule, Ještě ke správnímu soudnictví a jeho organizaci, Právní praxe 1994, nr 4, s. 188 i nast., I. Schelleová, Správní soudnictví, Praha 2004, s. 22 i nast. 
nego (Občanský soudní řád, dalej: o.s.ř. $)^{5}$ - Správní soudnictví - czyli przepisy zawarte w $\$ 244-250$ s o.s.ř. Uwzględniając potrzebę oraz konieczność prowadzenia długotrwałych i rzetelnych prac legislacyjnych wynikających z tej kardynalnej zmiany związanej z przygotowaniem odpowiedniego aktu normatywnego, dopiero od 1 stycznia 2003 r. zaczęła obowiązywać ustawa o postępowaniu przed sądami administracyjnymi ${ }^{6}$ (Zákon soudní rád správní dalej: s.řs.).

Współczesne sądownictwo administracyjne Republiki Czeskiej, którego podstawową funkcją jest ochrona publicznych praw podmiotowych, pozostaje powiązane $\mathrm{z}$ sądownictwem powszechnym. Postępowanie w sprawach sądowoadministracyjnych zostaje uruchomione po wyczerpaniu administracyjnych środków prawnych i opiera się na zasadzie skargowości. W sprawach tych orzekają wyspecjalizowane wydziały sądowoadministracyjne sądów okręgowych (Krajské soudy), a także Najwyższy Sąd Administracyjny (Nejvyšší správní soud, dalej: NSS) z siedzibą w Brnie ${ }^{7}$. W systemie sądownictwa administracyjnego działa także Sąd Miejski (Městský soud) w Pradze, rozstrzygający sprawy określone w części ósmej ustawy s.ř.s. (Řizení o zrušení služebního předpisu), dotyczące uchylenia regulaminu pracowniczego wydanego na podstawie ustawy o służbie cywilnej ${ }^{8}$. Kompetencje kontroli bezpośredniej i pośredniej w stosunku do administracji publicznej posiada również Sąd Konstytucyjny (Ústavní soud České republiky), o czym przesądza treść art. 87 ust. 1 Konstytucji Republiki Czeskiej ${ }^{9}$.

W tym kontekście podkreślenia wymaga, iż obecnie ponownie rozgorzała dyskusja $^{10}$ i zintensyfikowano prace, których celem jest odciążenie NSS ${ }^{11}$ poprzez no-

5 Zákon č. 99/1963 Sb. Szerzej zob. np. V. Mikule, V. Sládeček, Nad nálezem Ústavního soudu, kterým byla zrušena úprava správního soudnictví, Bulletin advokacie 2002, nr 10, s. 60 i nast.; V. Mikule, Pláč nad ztracenou př́ležitostí aneb Nejvyšši správní soud nebude přezkoumávat právní predpisy, Justiční Praxe 2002, nr 3, s. 85-90; J.M. Baxa, Reforma českého správního soudnictví, Právní rádce 2002, nr 1, s. 9 i nast.; L.Pitrova, Nejvy̌šś správní soud - dárek k desetiletí české ústavy, w: Deset let Ustavy České republiky. Východiska, stav, perspektivy, red. J. Kysela, Praha 2003, s. 36 i nast.; P. Varvařovský, Nejvyšši správní soud na startu, Justiční Praxe 2002, nr 3, s. 81-84. Podkreślenia wymaga, że jednym z celów reformy sądownictwa administracyjnego było spełnienie wymogów art. 6 ust. 1 Konwencji o ochronie praw człowieka i podstawowych wolności, por. wyrok NSS z dnia 31 maja 2007, č. j. 2 Afs 105/2006-90, www.nssoud.cz.

6 Zákon č. 150/2002 Sb. Ustawa była wielokrotnie nowelizowana, najbardziej obszerna zmiana została wprowadzona ustawą $\mathrm{nr}$ 303/2011 Sb.

7 Por. $\$ 3$ s.r.s.

$8 \$ 101$ e s.r.s.s.

9 Szerzej zob. D. Kryska, Konstytucyjny model czeskiego sądownictwa administracyjnego, Zeszyty Naukowe Sądownictwa Administracyjnego 2014, nr 1, s. 187.

10 Zob. Pismo Prezesa NSS z dnia 24 lipca 2018 r., Sp. zn. Sleg 3/2018, apps.odok.cz [dostęp: 20.01.2020 r.].

11 W 2019 r. średnia długość postępowania została przedłużona ze 178 do 195 dni, zob. też E. Paseková, P. Dimun w wywiadzie: Michal Mazanec: Dobrý soudce nevstupuje do prostoru vyhrazeného 
welizację ustawy -Zákon soudní rád správní - mającej na celu rozszerzenie podstaw niedopuszczalności skargi kasacyjnej, co pozwoliłoby mu skoncentrować się na bardziej skomplikowanych sprawach i nowych problemach prawnych. Rozważa się także reorganizację sądownictwa m.in. poprzez przesunięcie sędziów orzekających w sprawach karnych (za ich zgodą) do sekcji administracyjnej sądów okręgowych, a to w związku ze spadkiem przestępczości ${ }^{12}$ oraz utworzenie odrębnego sądownictwa administracyjnego, obsadzonego przez wyspecjalizowanych sędziów.

W świetle regulacji konstytucyjnej Republiki Czeskiej możliwy jest zarówno model jedno-, dwu-, jak i wieloinstancyjności czeskiego sądownictwa administracyjnego $^{13}$. Przeważa jednak pogląd, zgodnie z którym w czeskim dwustopniowym sądownictwie administracyjnym postępowanie jest jednoinstancyjne. $W$ rezultacie od wyroków nie przysługuje odwołanie ani inne zwykłe środki prawne. Ustawodawca wprowadził jednak katalog nadzwyczajnych środków prawnych (mimořádne opravne prostředki) przysługujących od orzeczeń prawomocnych, do których należą: skarga kasacyjna (kasační stížnos $\$ 102-110$ s.řs.s.) ${ }^{14}$ - o której orzeka NSS - oraz skarga o wznowienie postępowania (obnova ř́zení \$111-119 s.ř.s.) ${ }^{15}$, która ma charakter niedewolutywny.

Regulacja wznowienia postępowania sądowoadministracyjnego znajduje się w części trzeciej s.řrs. w tytule drugim. Podkreślenia wymaga, że zgodnie z przepisem $\$ 64$ s.ř.s., o ile soudní rád správní nie stanowi inaczej, przepisy pierwszej i trzeciej części Kodeksu postępowania cywilnego ${ }^{16}$, czyli przepisy ogólne i postępowanie przed sądem pierwszej instancji, stosuje się odpowiednio do postępowań przed sądami administracyjnymi. Jednak regulacja wznowienia postępowania sądowoadministracyjnego jest zupełna i kompleksowa, dlatego subsydiarne stosowanie o.s.r.r. wydaje się być wyłączone ${ }^{17}$.

správě, https://www.ceska-justice.cz o działaniach dotyczących przyspieszenia postępowania [dostęp: 16.01.2020 r.].

12 Advokátní Deník, https://advokatnidenik.cz, Česká televize, https://ct24.ceskatelevize.cz [dostęp: 16.01.2020 r.].

13 Zob. np. V. Mikule, Ještě ke správnímu..., s. 188, J.M. Baxa, Sąownictwo administracyjne w Czechach, Zeszyty Naukowe Sądownictwa Administracyjnego 2007, nr 2, s. 151; A. Ziółkowska, Postępowanie międzyinstancyjne..., s. 366-367, por. też wyrok (NALUS) Sądu Konstytucyjnego z dnia 6 listopada 2003 r., III. 150/03 N 128/31 Sb NU 149.

14 Zob. np. A. Ziółkowska, Postępowanie międzyinstancyjne..., s. 368-374.

15 W czeskim postępowaniu cywilnym mowa wprost o skardze o wznowienie postępowania (Žalobou na obnovu řizení), zob. \$228 Občanský soudní řád, Zákon č. 99/1963 Sb.

16 O.s.r.

17 Z. Kühn, w: Z. Kühn, T. Kocourek i in., Soudní rád správní. Komentář, Praha 2019, s. 1028, 1039 oraz wyrok NSS z dnia 4 stycznia 2009 r., 6 Ads 130/2008-21. 


\section{Przesłanki wznowienia postępowania sądowoadministracyjnego}

W pierwszej kolejności sygnalizacji wymaga, że do końca 2002 r. nie było możliwości złożenia skargi o wznowienie postępowania w świetle przepisów $₫ 250$ j i $\$ 250$ s Kodeksu postępowania cywilnego ${ }^{18}$, a jej złożenie skutkowało umorzeniem postępowania (zastavení rízení). Aktualnie obowiązująca regulacja postępowania sądowoadministracyjnego dopuszcza jego wznowienie wyłącznie w odniesieniu do wyroków o charakterze merytorycznym, mających przymiot prawomocności. Wznowienie postępowania ma charakter restytutycyjny, a jego celem jest usunięcie nieprawidłowości w zakresie ustaleń stanu faktycznego ${ }^{19}$, które ujawniono dopiero po uprawomocnieniu się orzeczenia. Jego istotą jest nie tylko obalenie wyroku rozstrzygającego o istocie sprawy, gdyż skuteczne wniesienie skargi o wznowienie powoduje ponowne rozpoznanie sprawy przy zastosowaniu przepisów o postępowaniu przed sądem I instancji (szczebla). Instytucja ta jednak znajduje zastosowanie tylko w tych przypadkach, w których sąd administracyjny działał jako sąd rozpoznawczy i sam dokonał ustaleń stanu faktycznego, a nie jedynie dokonywał kontroli działania lub bezczynności organu administracyjnego ${ }^{20}$. Jednocześnie, ze względu na charakter tego środka, możliwość wznowienia postępowania sądowoadministracyjnego jest znacznie ograniczona przepisami prawa ${ }^{21}$, ut infra.

Pozytywne przesłanki wznowienia postępowania zostały określone $\mathrm{w} \$ 111$ s.řs.s. Postępowanie zakończone prawomocnym wyrokiem może zostać wznowione na skutek skargi strony, jeżeli wyjdą na jaw dowody lub okoliczności, na które nie powołano się lub nie można było się powołać w trakcie postępowania sądowego, bez winy wnoszącego lub odmiennie rozstrzygnięto zagadnienie wstępne, jeżeli wynik wznowionego postępowania może być dla skarżącego korzystniejszy. Z dyspozycji wskazanego przepisu wynikają przesłanki określane w orzecznictwie mianem przesłanek materialnych ${ }^{22}$, tworząc następujące podstawy wznowienia postępowania sądowoadministracyjnego: nieznajomość okoliczności albo dowodów ${ }^{23}$ - jako klasyczne podstawy wznowienia postępowania - oraz odmienne rozstrzygnięcie kwestii prejudycjalnej ${ }^{24}$.

18 J. Vetešník, w: L. Jemelka i in., Správní rád soudní, komentár, Praha 2013, s. 988.

19 V. Vopálka, i in., Soudní rád správní. Komentář, Praha 2004, s. 287; F. Zoulík, Soudy a soudnictví, Praha 1995 , s.143.

20 Z. Kühn, w: Z. Kühn, T. Kocourek i in., Soudní rád..., s. 1028, 1032; I. Schelleová, Správní soudnictví, Praha, 2004, s. 84.

21 T. Foltas, L. Hlouch, Základy správního procesu, Brno 2009, s. 234.

22 Wyrok NSS (Nejvyšši správní soud) z dnia 10 listopada 2010 r., 3 Ans 29/2010-54, https://iudictum.cz.

$23 \$ 111$ s.r.s. ab initio.

$24 \$ 111$ s.r.s.s. in fine. 
Jak się wydaje, w zakresie pierwszej przesłanki wznowienia należy wyodrębnić dwie sytuacje, tj. wyjście na jaw nowych dowodów oraz wyjście na jaw nowych okoliczności. Zasadne staje się ustalenie, czy do wznowienia postępowania może dojść przy rozłącznym czy też kumulatywnym wystąpieniu nowych okoliczności i/lub nowych dowodów. Wydaje się, że prymat przysługuje w tym przypadku wykładni językowej i interpretacji przepisu w sposób literalny ${ }^{25}$, tzn. że przesłanką wznowienia postępowania jest albo wyjście na jaw dowodów, albo występowanie okoliczności istniejących, lecz nieznanych w czasie jego wydania, czyli $a$ verbis legis non est recedendum. O zasadności tego rozumowania przesądza użyta przez ustawodawcę w treści przepisu alternatywa zwykła „albo". Wskazać przy tym należy, że nieznajomość okoliczności albo dowodów dotyczy tak strony, jak i sądu. Przywołanie ich jako podstawy wznowienia jest uwarunkowane ich istnieniem w czasie wydania wyroku oraz niemożnością ich przywołania w postępowaniu sądowym bez winy strony, a także gravamen, ut infra.

Brak wiedzy w zakresie okoliczności powinien być rozumiany jako sytuacja, w której pojawily się fakty istniejące w momencie wydania wyroku, ale strona ich nie znała lub nie mogła $\mathrm{z}$ nich skorzystaćc ${ }^{26}$. Skoro przesłanką wznowienia są w tej sytuacji jedynie okoliczności, fakty (quaestio facti), stąd zmiany opinii prawnej lub orzecznictwa sądu administracyjnego nie mogą być uważane za nowe okoliczności lub dowody ${ }^{27}$ czy też wydanie orzeczenia Sądu Konstytucyjnego ${ }^{28}$.

Druga z przesłanek wznowienia postępowania określona $\mathrm{w} \$ 111$ s.r.s. ab initio, czyli wyjście na jaw dowodów, oznacza np. wyjawienie dokumentu uznanego za zaginiony lub zniszczony bądź pojawienie się świadka zdarzenia, którego tożsamość była nieznana w czasie orzekania zarówno sądowi, jak i stronie postępowania.

Wznowienie postępowania oparte na przesłance, wskazanej w $\$ 111$ s.řs.s. in in tra, odnosi się do sytuacji, w których sąd oparł się na orzeczeniu wydanym przez inny sąd, następnie zmienionym albo uchylonym, lub gdy sąd sam rozstrzygnął kwestię prejudycjalną, którą następnie odmiennie rozpoznał właściwy są $\mathrm{d}^{29}$. Zgodnie z treścią $\$ 52$ ust. 2 s.řs.s. sąd administracyjny jest związany wyrokiem sądu karnego oraz wyrokiem sądu cywilnego dotyczącym stanu cywilnego (rozhodnutím

$25 \$ 111$ s.řs. ab initio.

26 V. Vopálka, i in., Soudní rád..., s. 287; wyrok z dnia 14 stycznia 2009 r., sp. zn. 6 Ads 130/2008-21, www.nssoud.cz.

27 Postanowienie Sądu Okręgowego (Krajský soud Hradec Králové) z dnia 3 lipca 2019 r., č. j. 31 A 37/2017-118, www.nssoud.cz; M. Bobek, Z. Kühn, Wprowadzenie, w: M. Bobek, Z. Kühn, i in., Judikatura a právní argumentace, Praha 2013, s. 48.

28 Wyrok (Nález) Sądu Konstytucyjnego (Ústavního soudu) z dnia 2 października 2018 r. sp. zn. II. ÚS 2546/18, http://www.bulletin-advokacie.cz.

29 V. Vopálka, i in., Soudní rád..., s. 288. 
soudu o osobnim stavu), w pozostałych przypadkach może sam rozstrzygnąć zagadnienie wstępne. Jeżeli jednak kwestia prejudycjalna zostanie rozpoznana przez inny sąd, jest tym rozstrzygnięciem związany. Czeski ustawodawca nie ogranicza zatem możliwości wznowienia postępowania jedynie do pytań prawnych (kwestii wstępnych), którymi sąd jest związany ${ }^{30}$. Podkreślenia wymaga, że pytania w trybie prejudycjalnym skierowane do Trybunału Sprawiedliwości UE zgodnie z postanowieniami $\$ 48$ ust. 1 s.ř.s. nie mogą być jednak uznawane za orzeczenia w trybie prejudycjalnym. W takim przypadku sąd zawiesza postępowanie do czasu wydania orzeczenia przez Trybunał Sprawiedliwości UE.

Dopuszczalność wznowienia postępowania w czeskim postępowaniu sądowoadministracyjnym opiera się na koncepcji interesu prawnego w zaskarżeniu wyroku (tzw. gravamen ${ }^{31}$ ). Skarga nie może zatem zostać złożona przez stronę, której żądnie zostało w uprzednim postępowaniu w pełni uwzględnione ${ }^{32}$. Istotą wszakże gravamen jest domniemanie faktyczne, że zaskarżone rozstrzygnięcie jest dla skarżącego niekorzystne. W konsekwencji należy przyjąć, że interes prawny w zaskarżeniu powstaje, jeżeli rozstrzygnięcie zostało wydane niezgodnie z żądaniem lub wnioskiem strony. Ponadto interes ten należy wiązać bezpośrednio z określonym rozstrzygnięciem, a nie z innymi orzeczeniami będącymi konsekwencją procesową, jakie może lub mogło ono wywołać. Gravamen ma charakter formalnoprocesowy i podlega badaniu w fazie wstępnej, a jego brak skutkuje niedopuszczalnością środka prawnego.

Nadzwyczajny charakter wznowienia postępowania znajduje potwierdzenie także w przepisie $\$ 114$ s.ř.s. ograniczającym dopuszczalność skargi o wznowienie postępowania ze względu na postępowanie, w którym został wydany wyrok. Zgodnie wszakże $\mathrm{z}$ dyspozycją ust. 1 tego przepisu wznowienie postępowania jest dopuszczalne wyłącznie w odniesieniu do wyroków wydanych w dwóch rodzajach postępowań: w postępowaniach o ochronę przed bezprawną ingerencją organu administracyjnego oraz w postępowaniach w sprawie partii politycznych i ruchów politycznych.

Pierwszy rodzaj postępowań został uregulowany w $₫ 82$ i nast. s.ř.s. i odnosi się do ochrony przed bezprawną ingerencją, pouczeniem lub przymusem organu administracyjnego niemającymi formy decyzji, tj. ochrony przed „nieformalną” ingerencją w prawa podmiotowe ${ }^{33}$. Przykładem takiego działania organu może być niezgodna $\mathrm{z}$ prawem ingerencja organu nadzoru budowlanego ${ }^{34}$. W cze-

30 Z. Kühn, w: Z. Kühn, T. Kocourek i in., Soudní rád..., s. 1029.

$31 \$ 111$ s.r.s. in fine.

32 V. Vopálka, i in., Soudní rád..., s. 288.

33 Przed $2003 \mathrm{r}$. ta instytucja skargi była nieznana.

34 Postanowienie NSS z dnia 18 września 2012 r., 2 As 86/2010-76, https://iudictum.cz. 
skim orzecznictwie sądowym podkreśla się, że brak legalnej definicji interwencji, powodowany jest przede wszystkim tym, że zakres tego pojęcia (w rozumieniu $\$ 82$ s.řs.) obejmuje ogromną liczbę działań faktycznych organów administracyjnych, podejmowanych na podstawie równie dużej liczby aktów normatywnych. Do działań tych należą czynności nieformalne, takie jak np. instrukcje faktyczne (zazwyczaj $\mathrm{w}$ transporcie), natychmiastowe interwencje (ostrzeżenia, środki zaradcze), konfiskaty itp. Pomimo tego, że nie są podejmowane w formie decyzji, to wiążą podmioty, do których są skierowane ${ }^{35}$. Adresaci tych działań są zobowiązani do działania (zrobienia czegoś), powstrzymania się od jakiejkolwiek działalności lub znoszenia działania, przy tym instrukcje lub polecenia mogą zostać wyartykułowane zarówno na piśmie, jak i ustnie ${ }^{36}$. Dopuszczalność skargi w tych sprawach uzależniona jest od kumulatywnego spełnienia trzech przesłanek: ingerencji dokonuje organ wykonawczy lub inny organ określony w przepisach prawa, organ ten decyduje o prawach i obowiązkach osób fizycznych lub prawnych, a jego rozstrzygnięcie mieści się w granicach właściwości administracji publicznej ${ }^{37}$. Z kolei NSS w wyroku z dnia 17 marca 2005 r. wskazał na dodatkowe warunki dopuszczalności skargi w trybie $\$ 82$ s.řs.s. mianowicie: skarżący musi zostać w sposób bezpośredni pozbawiony praw poprzez niezgodną z prawem interwencję organów, pouczenie lub przymus nie mają formy decyzji administracyjnej, mają zostać skierowane bezpośrednio lub pośrednio przeciw skarżącemu, a interwencja lub jej konsekwencje mają charakter trwały lub potencjalnie powtarzalny ${ }^{38}$. Jednak przepisy prawne nie przewidują ochrony przed interwencjami przeszłymi czy przyszłymi ${ }^{39}$. Termin do wniesienia skargi w tych przypadkach wynosi dwa miesiące od daty, w której skarżący dowiedział się o interwencji, ale nie później niż dwa lata od momentu, w którym miała ona miejsce.

Wznowienie postępowania dopuszczalne jest również w dwóch rodzajach postępowań uregulowanych w części drugiej w tytule piątym s.řs.s. tj. odnoszących się do sprawy partii politycznych i ruchów politycznych. Regulacja tych postępowań została zawarta w przepisach $\$ 94$ i nast. s.r.s. i dotyczy kwestii rejestracji partii politycznej lub ruchu politycznego, zmiany ich statutu, rozwiązania ${ }^{40}$, zawieszenia lub wznowienia działalności. Postępowania w tych sprawach, związanych z kontrolą

35 Wyrok (Nalus) Sądu Konstytucyjnego z dnia 25 sierpnia 2008 r., I.ÚS 3001/07, nalus.usoud.cz.

36 Wyrok NSS z dnia 29 września 2009 r., 4 Ads 117/2009-53, https://oadvokatech.ospravedlnosti.cz; wyrok NSS z dnia 29 kwietnia 2005 r., 4 As 17/2004, https://iudictum.cz.

37 Wyrok NSS z dnia 21 maja 2008 r., sp. zn. 4 Ans 9/2007, www.nssoud.cz.

38 Wyrok NSS z dnia 17 marca 2005 r., sp. zn. 2 Aps 1/2005, iudictum.cz.

39 V. Vopálka, i in., Soudní ŕád..., s. 197.

40 Zob. np. wyrok NSS z dnia 13 czerwca 2019 r., Pst 11/2019-26, https://iudictum.cz. 
postępowania prowadzonego przez Ministra Spraw Wewnętrznych w związku z ich rejestracją lub rejestracją zmiany statutu, prowadzi Sąd Miejski w Pradze, pozostałe materie należą do właściwości NSS.

Enumeratywne pozytywne wyliczenie postępowań, w których dopuszczalne jest wznowienie postępowania sądowoadministracyjnego, stanowi swoistego rodzaju ich delimitację, stąd a contrario należy przyjąć, że wznowienie postępowania w innych niż powyższe jest niedopuszczalne ${ }^{41}$. Linia orzecznicza, odpowiadająca literalnemu brzmieniu przepisów, pozostaje w tym zakresie stała. Podkreśla się w nim, że w przypadku wniesienia skargi o wznowienie postępowania w innych sprawach niż wymienione (np. w sprawie przyznania zasiłku ${ }^{42}$ ) sąd odrzuca ją na podstawie $\$ 46$ ust. 1 pkt.d s.ř.s. w Zw. z $\$ 120$ s.ř.s. Tak samo postępuje NSS, gdy skargą o wznowienie postępowania zostanie zaczepiony wyrok wydany wskutek rozpoznania skargi kasacyjnej ${ }^{43}$, wznowienie postępowania bowiem w takim przypadku jest niedopuszczalne ${ }^{44}$. W konsekwencji należy przyjąć, że nawet jeśli warunki określone w przepisach $\$ 111$ s.ř.s. oraz $\$ 114$ ust. 1 s.řrs. zostają spełnione, to znaczy, jeśli zachodzą przesłanki pozytywne i skarga o wznowienie dotyczy jednego z dwóch wyżej wskazanych rodzajów postępowań przed sądami administracyjnymi, również wówczas wznowienie postępowania nie zawsze jest dopuszczalne. A contrario, jest ono dopuszczalne tylko wtedy, gdy nie jest to skarga o wznowienie postępowania, w którym rozstrzygnięto skargę kasacyjną ${ }^{45}$ bądź gdy skarga nie jest skierowana wyłącznie przeciwko uzasadnieniu wyroku lub rozstrzygnięciu w sprawie kosztów postępowania $^{46}$. Ratio legis tego ostatniego warunku dopuszczalności wznowienia jest jego admisja jedynie wówczas, gdy skarga odnosi się do istoty sprawy.

\section{Wszczęcie postępowania wznowieniowego}

Wznowienie postępowania sądowoadministracyjnego w czeskiej regulacji opiera się na zasadzie skargowości. W świetle regulacji zawartej w $\$ 112$ s.ř.s. stroną

41 Wyrok NSS z dnia 10 listopada 2010 r., 3 Ans 29/2010-54, https://iudictum.cz, zob. też postanowienie NSS z dnia 10 lipca 2012 r., Komp 1/2012-142, http://nssoud.cz.

42 Zob. np. wyrok NSS z dnia 30 kwietnia 2016 r., 4 Ads 81/2016-44, www.nssoud.cz.

43 Z. Kühn, w: Z. Kühn, T. Kocourek i in., Soudní rád..., s. 1033; wyroki NSS z dnia 8 czerwca 2016 r., č.j. 2 Ads 91/2016-41, z dnia 29 czerwca 2016 r., č. j. 6Ads 77/2016-39; wyrok NSS z dnia 3 listopada 2009 r., 3 Ads 106/2009-38, http://nssoud.cz.

44 Por. postanowienie NSS z dnia 4 marca 2010 r., Na 49/2010-25, https://iudictum.cz.

$45 \$ 114$ ust.2 s.r.s.s.

$46 \$ 114$ ust. 3 s.řs.s. 
postępowania jest osoba, która złożyła skargę o wznowienie postępowania, a także osoby, które były stronami postępowania sądowego zakończonego wyrokiem, na zasadzie skargowości, o ile od wyroku tego przysługuje ten środek. Biorąc pod uwagę powyższe rozważania dotyczące zakresu postępowań, w których omawiana instytucja jest dopuszczalna, należy przyjąć, że w postępowaniu odnoszącym się do ochrony przed bezprawną ingerencją organu - o którym mowa w $\$ 82$ s.řrs. stroną jest każdy, kto został bezpośrednio ograniczony w swoich prawach przez działanie organu niebędące decyzją administracyjną, zgodnie zaś z treścią przepisu $\$ 83$ s.řs.s. stroną jest także organ, który podjął interwencję. W przypadku interwencji np. sił zbrojnych czy publicznego korpusu zbrojnego, niebędącego organem administracyjnym lub członkiem takiego korpusu, stroną jest organ, któremu podlega. W postępowaniach tych stroną może być także osoba zainteresowana (osoby zúčastněné ${ }^{47}$. W przypadku drugiej kategorii postępowań stronami w których dopuszczalne jest wznowienie postępowania sądowoadministracyjnego - zgodnie z $\$ 94$ ust. 3 s.řr.s. - są podmioty określone w przepisach szczególnych, tzn. w Ustawie o partiach politycznych i ruchach politycznych (Zákon o sdružování v politických stranách a $v$ politických hnutích $)^{48}$. Z procedury rejestracji określonej w przepisach $\$ 6-11$ tej ustawy wynika, że stroną może być zarówno Minister Spraw Wewnętrznych, jak i partia polityczna lub ruch polityczny. W przypadku zawieszenia partii lub ruchu stroną jest rząd lub prezydent, a także partia polityczna lub ruch polityczny. Stroną postępowania wznowionego w tej kategorii spraw nie mogą być podmioty, o których mowa w $\$ 34$ s.řr.s. ${ }^{49}$.

Sądem właściwym do wznowienia postępowania jest ten, który wydał wyrok ${ }^{50}$, ponieważ skarga o jego wznowienie nie ma charakteru dewolutywnego, zatem jest to tak sąd okręgowy, jak i NSS ${ }^{51}$. W sprawach dotyczących rejestracji partii politycznych i ruchów lub zmian w statutach tychże orzeka Sąd Miejski (Městský soud) w Pradze. W sprawie wniosku o rozwiązanie partii politycznej lub ruchu politycznego, zawieszenia lub wznowienia działalności orzeka NSS. Jeżeli skarga o wznowienie postępowania zostanie wniesiona do sądu niewłaściwego miejscowo lub rzeczowo, zostanie przekazana zgodnie z właściwością ${ }^{52}$.

47 Por. $\$ 34$ s.řs.s., zob. też postanowienie NSS z dnia 18 września 2012 r., 2 As 86/2010-76, iudictum.cz; wyrok NSS z dnia 2 października 2008 r., č. j. 3 Aps 5/2008-282, iudictum.cz.

48 Ustawa z dnia 1 listopada 1991 r., Zákon č. 424/1991 Sb.

49 Por. Z. Kühn, w: Z. Kühn, T. Kocourek i in., Soudní rád..., s. 1031.

50 Zob. $\$ 113$ s.ř.s.

51 P. Hlavsa, Občanský soudní rád, Soudní rád správní a předpisy související súvodem kaplikaci komunitárního práva a kpředběžné otázce, Praga 2008, s. 598-599.

$52 \S 7$ ust. 5 s.ř̀s. 
Termin złożenia skargi o wznowienie postępowania sądowoadministracyjnego został określony w przepisie $₫ 115$ s.řs.s., z którego wynika, że może zostać wniesiona przez legitymowany podmiot w ciągu trzech miesięcy od daty, w której wnoszący skargę dowiedział się o przyczynie ponownego rozpatrzenia (termin subiektywny), ale nie później niż trzy lata po uprawomocnieniu się zaskarżonego wyroku (termin obiektywny). Pierwszy ze wskazanych terminów zaczyna biec od momentu faktycznego powzięcia informacji o przyczynie wznowienia, a nie od momentu, w którym skarżący mógł się tego dowiedzieć ${ }^{53}$. W razie wątpliwości zachowanie terminu subiektywnego może podlegać udowodnieniu. Drugi zaś termin biegnie od obiektywnie wyznaczonego momentu, tj. uprawomocnienia się wyroku. W tym miejscu podkreślenia wymaga, że zgodnie z dyspozycją $₫ 54$ ust. 5 s.řs. wyrok staje się prawomocny po doręczeniu stronom postępowania. Przy czym jego doręczenie na ma wpływu na uzyskanie przymiotu prawomocności wyroku ${ }^{54}$. Prawomocność zostaje potwierdzona na oryginale wyroku oraz jego odpisach. Od zachowania terminu obiektywnego ustawodawca przewidział jeden wyjątek, określony w $\$ 115$ ust. 2 in fine s.řs.s., tj. uchylenie wyroku karnego, którym sąd administracyjny był związany. Jak jednak wskazuje Z. Kühn, taka sytuacja od 2003 r. w praktyce sądowej nie wystąiła ${ }^{55}$.

Termin do wniesienia skargi o wznowienie postępowania ma charakter zawity i nie podlega przywróceniu. W przypadku wniesienia skargi spóźnionej sąd odrzuca ją, działając na podstawie $\$ 46$ ust. 1 pkt. d s.řs.s. w zw. z $\$ 120$ s.řs.s.

Skarga o wznowienie postępowania musi spełniać wymogi stawiane pismom procesowym, określone w przepisie $₫ 37$ ust. 3 s.řs. Oznacza to, że ze skargi musi jasno wynikać czego dotyczy, kto ją wnosi - imię i nazwisko skarżącego - adres do doręczeń, wskazanie żądania, a także oznaczenie daty i podpis. Jeżeli skargę należy doręczyć osobom zainteresowanym, musi zostać złożona odpowiednia liczba odpisów z wyjątkiem sytuacji, gdy skarga o wznowienie zostaje złożona elektronicz$n_{i}{ }^{56}$. Ponadto skarga musi spełniać wymagania szczególne określone w przepisie $\$ 116$ s.řs.s., do których należą:

1) wskazanie zaskarżonego wyroku (oznaczenie sądu, który wydał wyrok, data wydania oraz sygnatura oraz data uprawomocnienia wyroku, ut supra);

2) zakres, w jakim wyrok jest zaskarżany (tzn. w całości czy w części);

3) prawne uzasadnienie skargi (zgodnie $\mathrm{z} \ 111$ s.řs.);

4) wskazanie okoliczności potwierdzających zachowanie terminu do jej wniesienia;

53 V. Vopálka, i in., Soudní rád..., s. 289-290.

54 Z.Kühn, w: Z. Kühn, T. Kocourek i in., Soudní rád..., s. 456.

55 Tamże, s. 1034.

56 Tamże, s. 1034. 
5) przedstawienie dowodów potwierdzających zasadność skargi (np. dokumenty istotne dla sprawy, o których dowiedział się skarżący, wniosek o przesłuchanie świadka, który się ujawnił po uprawomocnieniu wyroku).

W przypadku wad skargi o wznowienia przewodniczący w drodze postanowienia wzywa do ich usunięcia w wyznaczonym terminie. Jeżeli uchybienia nie zostaną usunięte lub termin ich usunięcia zostanie przekroczony, a skardze nie można nadać dalszego biegu, sąd postanowieniem ją odrzuca (usnesením odmítne) ) $^{57}$. Wnoszący skargę o wznowienie postępowania musi zostać pouczony o skutkach zaniechania lub przekroczenia terminu ${ }^{58}$. Skarga może zastać odrzucona także z innych powodów, ut infra.

Skarga o wznowienie postępowania nie wywołuje skutku suspensywnego ex lege $e^{59}$, co wynika z zasady pewności prawa ${ }^{60}$. Sąd może jednak wstrzymać wykonanie wyroku na wniosek (odkladný účinek návrhu), stosując odpowiednio przepisy $\$ 73$ ust. 2-5 s.r.s. Wstrzymując wykonanie wyroku na wniosek, sąd bierze pod uwagę mogącą powstać nieodwracalną szkodę (nenahraditelnou újmu) ${ }^{61}$, chyba że wstrzymanie pozostawałoby w sprzeczności z interesem publicznym. Przy czym, jak podkreśla się $\mathrm{w}$ orzecznictwie sądowym, istnienie sprzecznego interesu publicznego nie jest wystarczające, aby odrzucić wniosek, jak mogłoby się wydawać $z$ literalnej interpretacji $\$ 73$ ust. $2^{62}$. Przed rozpoznaniem wniosku sąd weźmie pod uwagę stanowiska pozostałych stron postępowania. Sąd wydaje postanowienie w sprawie wstrzymania wykonania wyroku bez zbędnej zwłoki, nie później niż w ciągu 30 dni. Postanowienie to może zostać uchylone z urzędu lub na wniosek, jeżeli w trakcie postępowania okaże się, że nie było podstaw do przyznania skutku zawieszającego lub gdy przyczyny w międzyczasie odpadły.

Podkreślenia wymaga, że wykonanie zaskarżonego wyroku zostaje wstrzymane do momentu uprawomocnienia się nowego wyroku, wydanego we wznowionym postępowaniu, przez moc prawną postanowienia w sprawie dopuszczalności wznowienia postępowania wydanego w pierwszej fazie procedury wznowieniowej.

57 Por. $\$ 46$ s.ř.s. ust.1 pkt 1 in fine.

$58 § 37$ ust. 5 s.řr.s.

$59 \$ 117$ s.ř.s.

60 Tamże, s. 1035.

61 Postanowienie NSS z dnia 5 października 2004 r., čj. 6 Afs 25/2003-59, www.nssoud.cz.

62 Postanowienie NSS z dnia 6 sierpnia 2008 r., č.j. 5 As17/2008-131, publ.pod č.1698/2008Sb.NSS. 


\section{Przebieg postępowania}

Postępowanie ze skargi o wznowienie postępowania sądowoadministracyjnego składa się z dwóch etapów ${ }^{63}$, w każdym z nich, zgodnie z dyspozycją $\$ 120$ s.ř.s., stosuje odpowiednio przepisy części trzeciej, tytuł pierwszy (przepisy $\$ 32-64$ s.řs..). Postępowanie wszczyna się w dniu, w którym skarga wpłynęła do sądu. W pierwszej fazie postępowania wznowieniowego (iudicium rescindens) badaniu podlega dopuszczalność skargi. Czynności tych dokonuje sąd, do którego kierowana jest skarga o wznowienie postępowania. Przed rozstrzygnięciem o dopuszczalności wznowienia postępowania sąd administracyjny bada, czy istnieją procesowe przesłanki jej rozpatrzenia i może odrzucić skargę o wznowienie postępowania w drodze postanowienia.

Jak zasygnalizowano wyżej, w świetle $₫ 46$ s.řs.s. odrzucenie skargi o wznowienie postępowania na tym etapie może nastąpić, jeżeli:

1) skarga dotyczy wyroku, co do którego obowiązuje lis pendens;

2) jeżeli zachodzą wady nieusuwalne skargi albo wady usuwalne, które nie zostały naprawione w wyznaczonym przez sąd terminie, ut supra;

3) naruszono termin do jej wniesienia przez złożenie skargi zbyt wcześnie lub $\mathrm{z}$ uchybieniem terminu;

4) skarga została wniesiona przez osobę nieuprawnioną;

5) zachodzi oczywista bezzasadność skargi (np. nie było podstaw do jej złożenia);

6) skarga jest $z$ innych powodów niedopuszczalna (np. dotyczy wyroku kasacyjnego lub wyroku zapadłego w postępowaniu innym niż wskazane w $\$ 114$ s.r.s.s.).

Jeżeli sąd uzna skargę za uzasadnioną, dopuszcza wznowienie postępowania $\mathrm{w}$ drodze postanowienia. Ma ono przy tym charakter procesowy, uchyla prawomocność wyroku. Podobnie postanowienie odrzucające skargę o wznowienie należy rozumieć jako rozstrzygnięcie co do istoty dopuszczalności wznowienia. Nie jest to jednak rozstrzygnięcie merytoryczne $e^{64}$. Na postanowienie o wznowieniu postępowania, jak i na postanowienie odrzucające skargę o wznowienie przysługuje skarga kasacyjna ${ }^{65}$.

63 P. Prŭcha, Přezkoumání správních rozhodnutí, w: S. Skulová, i in., Správní právo procesní, Plzeň 2008. s. 314.

64 P. Hlavsa, Občanský soudní rád. Soudní rád správní, Praha 2006, s. 577.

65 Zob. np. wyrok NSS z dnia 29 września 2009 r., 4 Ads 117/2009-53, https://oadvokatech.ospravedlnosti.cz; S. Sedláček, Soudní kontrola veřejné správy, Brno 2011, s. 81. 
Zgodnie z zasadą dyspozycyjności skarga o wznowienie postępowania może zostać cofnięta do czasu wydania orzeczenia przez sąd ${ }^{66}$, co będzie skutkowało umorzeniem postępowania ${ }^{67}$.

W przypadku wydania postanowienia o dopuszczalności wznowienia sąd administracyjny przeprowadza drugi etap (iudicium rescissorium), tj. postępowanie wznowieniowe, w którym następuje merytoryczne rozpoznanie skargi. W celu prawidłowego ustalenia okoliczności istniejących w momencie wydania zaskarżonego wyroku przeprowadza nowo zaproponowane dowody. Sąd nie musi ponawiać przeprowadzonych dowodów, ale stanowią one dla niego bez wątpienia punkt wyjścia $^{68}$. Może zarządzić przeprowadzenie rozprawy, zawiadamiając o niej strony z co najmniej 10-dniowym wyprzedzeniem. Zasadniczo ma ona charakter jawny, o ile przewodniczący nie wyłączy jawności ze względu na okoliczności wskazane w $\$ 49$ ust. 2 zd. 2 s.r.s. Niemniej sąd może rozpoznać sprawę bez rozprawy, jeżeli strony zaproponowały taką formę lub nie wyraziły na nią sprzeciwu ${ }^{69}$. Sąd, co do zasady, jest związany uzasadnieniem skargi. Nie może zatem przekraczać zakresu skargi o wznowienie nawet, jeżeli wie o dowodach albo okolicznościach, które nie zostały wskazane przez wnoszącego ${ }^{70}$. Nie dotyczy to sytuacji, gdy kwestionowany wyrok dotyczy materii, o której sąd nie orzekł.

We wznowionym postępowaniu sąd nie uchyla zaczepionego skargą wyroku, lecz wydaje nowy. Dopuszcza się również możliwość wydania wyroku o tej samej treści ${ }^{71}$. Od wyroku podjętego we wznowionym postępowaniu przysługuje skarga kasacyjna. W nowym wyroku sąd rozstrzyga ponadto w sprawie kosztów wznowieniowego postępowania ${ }^{72}$.

\section{Zakończenie}

Regulacja wznowienia postępowania sądowoadministracyjnego w Republice Czeskiej ma charakter kompleksowy i zupełny w takim znaczeniu, że została ujęta

$66 \$ 37$ ust. 5 s.řs.s. w zw. $\mathrm{z} \$ 120$ s.řs.s.

$67 \$ 48$ lit. a s.r.s.s. w Zw. $\mathrm{z} \$ 120$ s.r.s.s.

68 Z. Kühn, w: Z. Kühn, T. Kocourek i in., Soudní rád..., s. 1037.

$69 \$ 51$ s.r.s.

70 Tamże, s. 1036.

71 Tamże, s. 1037, P. Hlavsa, Občanský soudní rád..., s.578.

72 Zob. $\$ 61$ s.řs.s. 
w jednym autonomiczny akcie normatywnym, bez konieczności odpowiedniego stosowania procedury cywilnej.

Wznowienie postępowania sądowoadministracyjnego uruchomionego w skutek wniesienia skargi stanowi wyjątek od zasady prawomocności formalnej orzeczenia $^{73}$. Jego uruchomienie na skutek skargi wniesionej przez legitymowany podmiot $\mathrm{z}$ jednej strony niewątpliwie czasowo narusza stabilność porządku prawnego wynikającego z zaczepionego skargą wyroku, ale z drugiej stwarza możliwość jego kontroli przez sąd, który go wydał, przyczyniając się z ten sposób do budowania autorytetu zarówno sądownictwa administracyjnego, jak i całego wymiaru sprawiedliwości.

Wznowienie postępowania sądowoadministracyjnego zostało oparte na zasadzie skargowości, przy czym cechą znamienną czeskiej skargi o wznowienie postępowania jest to, że nie ma powszechnego charakteru, gdyż nie przysługuje na wszystkie prawomocne orzeczenia sądów administracyjnych, co potwierdza jej nadzwyczajny charakter. Sporadyczność wykorzystania tej instytucji wynika $\mathrm{z}$ dwóch powodów: po pierwsze przesłanki pozytywne ${ }^{74}$ znajdują zastosowanie tylko wtedy, gdy sąd administracyjny sam ustalał stan faktyczny w sprawie, co nie jest częste z uwagi na istotę procedury sądowoadministracyjnej. Drugą zaś przyczyną ograniczonej liczby postępowań wznowieniowych jest enumeracja pozytywna procedur, w których znajduje zastosowanie. Jak się wydaje, takie określenie granic prawnych wykorzystania tego środka nadzwyczajnego wynika z potrzeby zagwarantowania stabilności merytorycznego prawomocnego wyroku, czyniąc jednocześnie instytucję wznowienia postępowania rzadko wykorzystywaną w praktyce sądowej. Dodatkowo podkreślenia wymaga, że skarżący musi legitymować się interesem w zaskarżeniu wyroku (gravamen), stanowiącym warunek dopuszczalności skargi o wznowienie postępowania sądowoadministracyjnego ${ }^{75}$.

Skarga o wznowienie postępowania nie ma charakteru dewolutywnego, do jej rozpoznania bowiem właściwy jest sąd, który ostatnio orzekał w sprawie, zatem jej wniesienie nie uruchamia kontroli instancyjnej. Jest także środkiem prawnym o samodzielnym charakterze, a jej wniesienie nie jest związane z koniecznością

$73 \$ 54$ ust. 5 s.ř.s.

74 Odmienne niż w polskim postępowaniu sądowoadministracyjnym: art. 271 ustawy - Prawo o postępowaniu przed sądami administracyjnymi (dalej: p.p.s.a.) (przyczyny nieważnościowe wznowienia), art. 272 p.p.s.a. (orzeczenie Trybunału Konstytucyjnego o niezgodności aktu normatywnego, na podstawie którego zostało wydane orzeczenie), art. 273 (przyczyny restytucyjne).

75 W polskim postępowaniu sądowoadministracyjnym skarżący nie musi legitymować się interesem w zaskarżeniu utożsamiany z gravamen. Szerzej zob. np. H. Knysiak-Molczyk, Skarga kasacyjna w postępowaniu sądowoadministracyjnym, Warszawa 2009, s. 195-196, A. Ziółkowska, Postępowanie międzyinstancyjne..., s. 206-207. 
dokonania innej czynności w postępowaniu. Ponadto skarga o wznowienie postępowania nie ma charakteru bezwzględnie suspensywnego.

O nadzwyczajnym charakterze tego środka świadczy również termin do jej wniesienia. Trzymiesięczny okres bowiem zaczyna biec od momentu, w którym skarżący dowiedział się o podstawach wznowienia postępowania, jednocześnie skarżący musi wskazać i opisać wszystkie okoliczności, które mogą potwierdzić terminowość wniesienia skargi. Podkreślenia wymaga, że czeski ustawodawca wskazał tzw. prekluzję wniesienia skargi o wznowienie postępowania, co należy ocenić pozytywnie, gdyż rozwiązanie to stanowi lepszy gwarant pewności obrotu prawnego przez uniemożliwienie wniesienia jej w dowolnym czasie.

Postępowanie prowadzone ze skargi o wznowienie postępowania ma charakter dwuetapowy, różny ze względu na przedmiot badania, przy czym każda z faz ma sformalizowany charakter. Pierwszy etap to postępowanie w przedmiocie wznowienia (postępowanie wstępne), obejmujący badanie zachowania warunków rozpoznania skargi o wznowienie, który kończy się dopuszczalnością wznowienia lub odrzuceniem skargi ${ }^{76}$. Drugi zaś to wznowione postępowanie prowadzone zasadniczo w zakresie wskazanym przez skarżącego.

W końcowej konkluzji należy zgłosić w zakresie wniosków de lege ferenda rozważenie wprowadzenia przez czeskiego ustawodawcę $\mathrm{w}$ procedurze sądowoadministracyjnej przepisów regulujących niedopuszczalność dalszego wznowienia postępowania zakończonego prawomocnym orzeczeniem wydanym na skutek skargi o wznowienie postępowania (restitutio restitutionis non datur), czyli w istocie gwarantujących jednorazowość tej procedury.

\section{Bibliografia}

Baxa J.M., Reforma českého správního soudnictví, Právní rádce 2002, nr 1.

Baxa J.M., Sądownictwo administracyjne w Czechach, Zeszyty Naukowe Sądownictwa Administracyjnego 2007, nr 2.

Bobek M., Kủhn Z., Wprowadzenie, w: M. Bobek, Z. Kủhn, i in., Judikatura a právní argumentace, Praha 2013.

Foltas T., Hlouch L., Základy správního procesu, Brno 2009.

$76 \mathrm{~W}$ polskim postępowaniu sądowoadministracyjnym wynikiem badania jest wyznaczenie rozprawy bądź odrzucenie skargi. Na rozprawie sąd rozstrzyga przede wszystkim o dopuszczalności wznowienia i jeżeli brak jest ustawowej podstawy wznowienia lub termin do wniesienia skargi nie został zachowany, odrzuca skargę o wznowienie. Sąd może jednak po rozważeniu stanu sprawy połączyć badanie dopuszczalności wznowienia z rozpoznaniem sprawy. 
Hlavsa P., Občanský soudní rád. Soudní rád správní, Praha 2006.

Hlavsa P., Občanský soudní rád, Soudní řád správní a předpisy související súvodem kaplikaci komunitárního práva a kpředběžné otázce, Praga 2008.

Knysiak-Molczyk H., Skarga kasacyjna w postępowaniu sądowoadministracyjnym, Warszawa 2009.

Kryska D., Konstytucyjny model czeskiego sądownictwa administracyjnego, Zeszyty Naukowe Sądownictwa Administracyjnego 2014, nr 1.

Kühn Z., w: Kühn Z., Kocourek T. i in., Soudní rád správní. Komentářr, Praha 2019.

Mikule V., Pláč nad ztracenou príležitostí aneb Nejvyšši správni soud nebude přezkoumávat právní predpisy, Justiční Praxe 2002, nr 3.

Mikule V., Ještě ke správnímu soudnictví a jeho organizaci, Právní praxe 1994, nr 4, s. 188 i nast., I. Schelleová, Správní soudnictví, Praha 2004.

Mikule V., Sládeček V., Nad nálezem Ústavního soudu, kterým byla zrušena úprava správního soudnictví, Bulletin advokacie 2002, nr 10.

Paseková E., Dimun P. w wywiadzie: Michal Mazanec: Dobrý soudce nevstupuje do prostoru vyhrazeného správě, https://www.ceska-justice.cz [dostęp: 16.01.2020].

Pitrova L., Nejvyšši správní soud - dárek k desetiletí české ústavy, w: Deset let Ústavy České republiky. Východiska, stav, perspektivy, red. J. Kysela, Praha 2003.

Prŭcha P., Přezkoumání správních rozhodnutí, w: S. Skulová, i in., Správní právo procesní, Plzeň 2008.

Schelleová I., Správní soudnictví, Praha 2004.

Sedláček S., Soudní kontrola veřejné správy, Brno 2011.

Sládeček V., Tomaszková V., Správní soudnictví v České republice a ve vybraných státech Evropy, Praha 2010.

Tomaszková V., Tomoszek M., Vliv Rady Evropy na správni soudnictvi a přistup ke správnim soudiom v Českè republice, w: Vliv EU a Rady Evropy na správni řizeni v ČR a v Polsku, red. M. Horáková, M. Tomaszek, Brno 2010.

Varvařovský P., Nejvyšši správní soud na startu, Justiční praxe 2002, nr 3.

Vetešník J., w: L. Jemelka i in., Správní rád soudní, komentář, Praha 2013.

Vopálka V. i in., Soudní rád správní. Komentář, Praha 2004.

Ziółkowska A., Postępowanie międzyinstancyjne w postępowaniu sądowoadministracyjnym, Katowice 2019.

Zoulík F., Soudy a soudnictví, Praha 1995. 
